\title{
LAS ASOCIACIONES DE CONSUMIDORES Y USUARIOS, Y LA SANIDAD*
}

Juan José Llovet

RESUMEN. Hasta ahora, las asociaciones de consumidores y usuarios españoles no han sido prácticamente estudiadas. Aquí se procura contribuir al conocimiento de sus perfiles y fun. cionamiento, a través de la descripción y el análisis de su actuación respecto a la Sanidad Pública y Privada. Son abordadas las entidades de ámbito nacional y una del ámbito catalán que está específicamente dedicada a materias médico-sanitarias. Siendo todavía débil su desarrollo y tímida su inserción social, el examen de las reclamaciones, quejas y consultas que reciben - las cuales parecen estar aumentando gradualmente-, así como sus posibilidades participativas en algunos órganos de control de los estándares asistenciales, ponen de manifiesto la utilidad que están llamadas a tener estas organizaciones en el futuro.

\section{INTRODUCCION}

Pese a su elogiable misión en cuanto a la protección de ciertos derechos de los ciudadanos, lo cual de por sí las convierte en un atractivo campo de indagación, las asociaciones de consumidores y usuarios de España han sido escasamente estudiadas. Tal vez esa escasez no sea fortuita, y se deba a que

* Este trabajo está basado en una de las partes de un proyecto en curso acerca de los controles sociales sobre la práctica y la profesión médicas en España. Dicho proyecto es posible gracias a una beca concedida dentro del Subprograma de Estancias de Científicos y Tecnólogos Extranjeros, del Plan Nacional de Investigación Científica y Desarrollo Tecnológico. Su director es Ludolfo Paramio, a quien agradezco sus comentarios y permanente estímulo. 
esas entidades son una realidad larvada, germinal. Su verdadero despegue recién se produjo en la década pasada. Esta juventud o bisoñez institucional es uno de los factores que tienen que ver con que todavía sean bastante tímidas su gravitación e inserción en una sociedad que se distingue de otras de su entorno por no haber cultivado una tradición de salvaguardia del mundo del consumo. Las asociaciones de consumidores y usuarios españoles son ciertamente fruto de iniciativas de la sociedad civil. Pero este marcha. mo fundacional está subordinado a su marcada heteronomía respecto al Estado, que les ha dado la plataforma legal para su emergencia y, sobre todo, les aporta el auxilio financiero esencial para su mantenimiento.

El input de la actividad de estas organizaciones son reivindicaciones y exigencias formuladas por sujetos que han adquirido, utilizado o disfrutado como destinatarios finales bienes, servicios o productos; en mercados privados o públicos. Es decir, consumidores y usuarios que buscan apoyo porque estiman que sus intereses han sido dañados. Por añadidura, el output de intervención y control de estas entidades puede proyectarse virtualmente hacia empresas, comercios, bancos, particulares, determinados organismos estatales o paraestatales, etc. $\mathrm{Y}$, asimismo, servicios y profesionales médicosanitarios.

La meta de este artículo es describir y analizar la actuación de las asociaciones de consumidores y usuarios precisamente en relación a la Sanidad. ¿Por qué he elegido este sector como el ángulo desde el cual mirarlas y contribuir al conocimiento de su funcionamiento y perfiles?

En ciertas franjas de la población parece anidar una atmósfera de malestar frente a la asistencia médica y sanitaria. Así lo han reflejado algunas encuestas, que trasuntan descontento por la performance de la Sanidad Públi$\mathrm{ca}^{1}$. El desasosiego e irritación ante defectos sistémicos, como las listas de espera o las demoras en las urgencias, se hacen explícitos en las recurrentes denuncias de los lectores en sus cartas a los periódicos y en las quejas contenidas en los informes anuales del Defensor del Pueblo o de cualquiera de los ombudsmen autonómicos. Por otro lado, paulatinamente va dejando de ser una rara avis que un galeno sea querellado o demandado judicialmente por haber obrado con descuido o negligencia en su práctica profesional ${ }^{2}$.

1 Por ejemplo, en el Estudio 1733 del Centro de Investigaciones Sociológicas, la atención médica de la Seguridad Social - con una media de 4,59, en una escala del 0 al 10 - era el servicio o equipamiento público peor valorado (Cruz Cantero, 1988, pp. 85 a 88). Según un sondeo de la empresa Demoscopia en vísperas de las últimas elecciones legislativas generales, la Sanidad en ambulatorios y hospitales públicos era el ítem, sólo superado por el paro y el empleo, sobre el que más interesaba que los políticos debatieran en la campaña (El País, 24 de septiembre de 1989 , pp. 16 y 17 ).

2 De acuerdo a mi revisión de la jurisprudencia, entre 1870 y el 31 de diciembre de 1989, la Sala de lo Penal del Tribunal Supremo dictó 62 sentencias sobre imprudencias de médicos. Treinta y ocho eran de la última década. Mientras tanto, la Sala de lo Civil había dictado 26 sobre culpa médica contractual o extracontractual, de las cuales 16 pertenecían al lustro 1985-89. Mucho más expresivos que estos datos son los que recogí en los niveles inferiores de la Administración de Justicia en abril de 1990. En ese momento, en 20 de los 
Todos los Colegios de Médicos tienen suscritas pólizas colectivas para cubrir a sus miembros en caso de ser condenados a indemnizar a pacientes. $\mathrm{Y}$ hasta el Instituto Nacional de la Salud (INSALUD) ha terminado por hacer lo propio con su personal, mediante un seguro con vigencia desde el 1 de enero de 1991 (Diario 16, 17 de abril de 1991, p. 13). La magnitud del fenómeno de juicios contra facultativos está aún a una abismal distancia de la que ha tenido en países como Estados Unidos, pero, insisto, hoy ya no son tan excepcionales como antes.

La intersección temática asociaciones de consumidores y usuarios/Sanidad puede ser fructífera por dos razones. En primer término, porque las prestaciones de ese sector entrañan una serie de avatares que pueden afectar severamente la salud y el bolsillo de los ciudadanos, y son un área harto interesante en la que acotar un examen acerca de cómo se desenvuelven tales entidades. En segundo, porque, a su vez, las organizaciones de consumidores son uno de los canales formales por intermedio de los cuales los pacientes y usuarios pueden transformar su resignación o su protesta muchas veces sorda ante los fallos, las anomalías y las irregularidades, en reclamaciones y gestos concretos de reafirmación de sus derechos. Aproximarse a estas organizaciones permite explorar si, en efecto, está cambiando en algo el comportamiento de los pacientes y usuarios, con qué intensidad y ante qué problemas y, como contrapartida, cuál es la reacción de las estructuras y los agentes médicos y administrativos.

El trabajo de campo en que se basó la elaboración de este artículo ha consistido en: recolección de datos en el Instituto Nacional de Consumo (INC); visitas a las siete asociaciones de ámbito nacional, incluyendo observación participante, entrevistas a sus miembros, recogida de información cuantitativa y cualitativa y revisión de expedientes; e intercambios telefónicos y por carta con una entidad de usuarios de la Sanidad de Cataluña. El corpus empírico obtenido por estos métodos está complementado por noticias y otros textos periodísticos, extraídos de la prensa diaria.

La exposición está dividida en cuatro partes. En la primera se da un bosquejo global del movimiento asociativo en España. La segunda versa sobre la actuación de las organizaciones de ámbito nacional en lo referente a la Sanidad. La tercera se centra en la entidad catalana que actúa específicamente en materias médico-sanitarias. La cuarta son unas reflexiones finales de cara al futuro.

Juzgados de Instrucción ubicados en la Plaza de Castilla de Madrid había un total de 76 causas "vivas" - en diligencias previas - en las que estaban siendo investigados facultativos. $O$ sea, una media de 3,8 causas por Juzgado. 


\section{ALGUNOS DATOS GENERALES SOBRE EL ASOCIACIONISMO DE LOS CONSUMIDORES EN ESPAÑA}

Acerca de este asociacionismo pueden rastrearse algunos antecedentes aislados en las etapas finales del franquismo. En 1971 se crea el Consejo de Comercio Interior y de los Consumidores, en la órbita del Ministerio de Economía y Comercio; en 1973 se otorga la primera subvención oficial a una entidad. Durante esos años y los inmediatamente subsiguientes hubo balbuceos organizativos, algunos de ellos liderados por personas que habían estado próximas a los círculos de poder en el régimen autoritario.

La Constitución de 1978 - una de las pocas que consagra explícitamente este aspecto- reconoció el amparo a los consumidores y usuarios. El artículo 51 , en los puntos 1 y 2 , determina que los poderes públicos ugarantizarán la defensa de los consumidores y usuarios, protegiendo, mediante procedimientos eficaces, la seguridad, la salud y los legítimos intereses de los mismos", y "promoverán la información y la educación de los consumidores y usuarios, fomentarán sus organizaciones y oirán a éstas en las cuestiones que puedan afectar a aquéllos, en los términos que la Ley establezca». Queda así recogida en el máximo nivel normativo una problemática que ya tenía relevancia en otros países europeos y en los Estados Unidos.

Pero la sanción de la Carta Magna no acarreó por sí sola ni automáticamente una mayor inquietud política y social por la protección de los consumidores. Un hecho anecdótico pero sintomático es que, en las postrimerías del gobierno de Adolfo Suárez, el Instituto Nacional de Consumo permaneció vacante durante más de un mes, lo cual era interpretado por la prensa en estos términos: "... parece que el cargo de presidente de esta entidad autónoma ronda de mesa en mesa por el Ministerio de Comercio sin que, hasta el momento, nadie quiera hacerse cargo de él, ya que, dentro de la Administración, los cargos oficiales relacionados con el consumo están catalogados como una degradación o una condena al ostracismon (El Pats, 4 de febrero de 1981, p. 21; cursiva en el original). Pocos meses después de este comentario, el ostracismo cultural y administrativo de esta problemática era quebrado por una tragedia de escala nacional: el envenenamiento masivo causado por el fraudulento desvío al consumo humano de aceite de uso industrial desnaturalizado con anilina. La epidemia de la colza o síndrome tóxico, que irrumpió en la primavera de 1981, constituyó la intoxicación más grave de la historia de España, con un saldo de más de 650 muertos y cerca de 25.000 afectados en diversos grados. Cifras dramáticas, y tan espectaculares como las de sus derivaciones judiciales: un sumario de 250.000 folios, 40 encausados, declaraciones de más de 2.000 testigos, más de 200 peritos (42 de ellos, especialistas extranjeros), quince meses de vista oral, etc. El 20 de mayo de 1989 un tribunal de la Audiencia Nacional dictó la sentencia, actualmente recurrida ante el Tribunal Supremo, perdurando aún sin resolverse el espinoso problema de las indemnizaciones. En una interpelación en 
el Congreso, el ministro de Relaciones con las Cortes recordó que "entre 1981 y 1989 los gobiernos han gastado 55.000 millones de pesetas en el sisiema de protección establecido [para las víctimas y los daminificados], sin contar los gastos de hospitalización, pensiones, becas y ayuda familiar complementaria" (El País, 1 de junio de 1989, p. 23).

La ilícita comercialización y la fatídica ingesta del aceite adulterado pusieron abruptamente de manifiesto la precariedad del país en cuanto a la fiscalización, la seguridad y los controles alimentarios. La población se dio cuenta de su indefensión ante posibles embaucadores y la Administración asumió la necesidad de prevenir a toda costa la repetición de acontecimientos de esta índole. El Código Alimentario fue revisado y ampliado, publicándose entre 1983 y 1986 alrededor de 60 disposiciones que completaron prácticamente su desarrollo. La preocupación se generalizó a todos los rubros del consumo y cristalizó en un marco jurídico global. Ante el inminente ingreso de España a la Comunidad Europea, que forzaba a adecuar la normativa a los patrones comunitarios, y en cumplimiento de la promesa del gobierno socialista de aprobarla durante su primer mandato, con el acuerdo de todos los grupos parlamentarios se sanciona la Ley General para la Defensa de los Consumidores y Usuarios (26/84, de 19 de julio). La Ley estableció, entre otros puntos, la obligatoriedad de que todos los productos llevaran una etiqueta con los datos de producción y composición, un sistema de sanciones para los infractores de las normas de control sanitario, y medidas para vigorizar las asociaciones de consumidores. Las Autonomías, por su lado, también confeccionaron ragulaciones, pudiéndose consignar la Ley $10 / 81$, de 18 de noviembre, sobre estatuto del consumidor del País Vasco; la Ley $12 / 84$, de 28 de diciembre, sobre estatuto gallego del consumidor y usuario; la Ley $5 / 85$, de 8 de julio, de los consumidores y usuarios en Andalucía; la Ley $2 / 87$, de 9 de abril, de estatuto de consumidores y usuarios de la Comunidad Valenciana; y la Ley $1 / 90$, de 8 de enero, sobre la disciplina del mercado y de defensa de los consumidores y de los usuarios de la Comunidad Autónoma de Cataluña.

Paralelamente, se fue gestando un entramado institucional, con una vertiente pública y otra privada. Dentro de la primera, amén del propio INC y las Consejerías autonómicas respectivas, hay que destacar las Oficinas Municipales de Información al Consumidor (OMICs), que a mediados de 1989 ascendían a 425 , cubriendo el $70 \%$ de la población.

La segunda está compuesta por las asociaciones. Aunque en los últimos tiempos es evidente una mayor estabilización y una tendencia hacia formas de articulación cada vez más agregadas, se trata de un universo atomizado, de evolución fluida y creciente respecto a su número, en cuya trayectoria han abundado las separaciones, fusiones, cambios de siglas, etc. Al 31 de diciembre de 1983, el censo del INC arrojaba 88 organizaciones (Servicio de Organizaciones de Consumidores, 1984, pp. 211 y 212); en diciembre de 1986, 157 (Ministerio de Sanidad y Consumo, 1989, p. 249). A fines de 
1989 había registradas 192; y en junio de 1990, 217. Muchas de ellas están integradas en las asociaciones o federaciones de ámbito nacional, que son siete: Asociación General de Consumidores (ASGECO); Confederación Estatal de Consumidores y Usuarios (CECU); Federación Española de Asociaciones de Amas de Casa, Consumidores y Usuarios (FEACCU); Federación de Usuarios-Consumidores Independientes (FUCI); Organización de Consumidores y Usuarios (OCU, unitaria, con sede en Madrid); Unión de Consumidores de España (UCE); y Federación Unión Cívica Nacional de Consumidores y Amas de Hogar de España (UNAE). Los orígenes de algu. nas de ellas son bastante contrastantes. Por ejemplo, mientras la FEACCU proviene del reciclaje de las agrupaciones de amas de casa ligadas a la Sección Femenina del extinto Movimiento Nacional, la UCE nace en 1987 a impulso de la Unión General de Trabajadores y otros grupos de extracción socialista. Pese a que la independencia respecto a los partidos es una propiedad firmemente proclamada por todas, varían en sus afinidades ideológicas y políticas, detectándose un talante más progresista en la FUCI, la CECU y la UCE.

Hay que advertir que con las censadas en el INC no se agota el número de asociaciones en funcionamiento, habiendo otras inscritas en Comunidades Autónomas y Ayuntamientos.

Una constante que atraviesa al conjunto del movimiento asociativo es su incapacidad de autofinanciación. Constante que ha sido paliada merced a las subvenciones oficiales. Las concedidas por el INC, que en 1981 no llegaban a los 50 millones de pesetas, estaban por encima de los 500 millones en 1988. En este último año se dictó la Orden Ministerial, de 3 de marzo, sobre normas para el apoyo y fomento de las asociaciones de consumidores y usuarios. Los criterios para la asignación de los subsidios son el volumen de asociados, el grado de implantación territorial, los programas en ejecución por sectores específicos y prestaciones, etc. La ayuda oficial es imprescindible debido a las dificultades de generar recursos propios, vía cuotas de socios. Según estimaciones de las mismas asociaciones de ámbito nacional, al primer trimestre de 1990, sus socios - los directamente afiliados a ellas más los de sus entidades autonómicas y provinciales confederadas o vinculadas - se elevaban aproximadamente a las siguientes cantidades: FEACCU, 300.000; FUCI, 213.000; UCE, 140.000; OCU y. ASGECO, sendos 70.000; CECU, 65.000; y UNAE, 22.500. Su adición alcanzaría un total que estaría entre los 850.000 y los 900.000 . Algo así como un 2 por 100 de la población española, contra el 0,78 por 100 que se calculaba para 1982. Pero estos guarismos son, en cierto modo, puramente nominales respecto a su genuina impronta financiera. Algunas entidades hasta hace poco ni siquiera cobraban cuotas. En las que lo hacen, ciertas categorías de socios están eximidas de pago, fijándose por lo general para las restantes montos muchas veces simbólicos, con un rango que podía ir -a principios de 1990 - de las 800 pesetas anuales a unas 4.000 a lo sumo. Entretanto, en 
países como Holanda una de cada cuatro familias está afiliada a una asociación nacional de consumidores, y "los consumidores europeos pagan cuotas que en ningún caso son inferiores a 5.000 pesetas anuales, que incluyen normalmente la suscripción a la revista de la asociación". Tales revistas brindan información técnica y análisis comparativos sobre productos y servicios que están en el mercado. Una de ellas, Wbich, de Gran Bretaña, edita un millón de ejemplares, 800.000 entregados por suscripción y 200.000 que se venden en quioscos (Pérez Oliva, 1989, p. 2).

Lógicamente, las subvenciones - con las que se procura solventar los gastos más elementales de mantenimiento y las campañas- y los escasos ingresos por afiliaciones no bastan para contar con presupuestos que permitan sostener organizaciones muy potentes. Las limitaciones económicas se traducen en la estrechez de recursos físicos y de gestión y en la falta de técnicos y especialistas, cada vez más necesarios a la hora de asesorar y orientar en una arena tan compleja y múltiple como la del consumo. Con todo, en algunas se nota un considerable esfuerzo por abandonar un umbral vegetativo y vertebrar estructuras más expansivas y orgánicas.

Estas contingencias no son casuales. Su background es el aún tenue grado de conocimiento y de predisposición participativa de la sociedad española en este terreno. A tenor de una encuesta del Centro de Investigaciones Sociológicas administrada en marzo de 1988, solamente el 19 por 100 de la población había oído hablar de la existencia de las asociaciones privadas de consumidores. Esta proporción subía con el nivel de estudios de los encuestados: 9 por 100 en los de menos de primarios, 18 por 100 en los de primarios, 23 por 100 en los de bachiller y 40 por 100 en los de superiores. También con el nivel de renta, pasando del 12 por 100 entre los de ingresos familiares mensuales inferiores a 50.000 pesetas al 33 por 100 entre los de más de 100.000. A su vez, de las personas que habían oído hablar de las asociaciones, apenas el 17 por 100 podía mencionar concretamente el o los nombres de alguna/s. Por último, ante la pregunta sobre si se estaría de acuerdo en formar parte de una asociación - afiliarse y pagar la cuota-, un 11 por 100 de los encuestados contestaba resueltamente que sí, un 21 por 100 lo condicionaba a ver cómo funcionan, un 48 por 100 respondía negativamente, y un 20 por 100 no sabía o no contestaba. Ninguna variable sociodemográfica (edad, sexo, educación, renta, tamaño del hábitat) introducía diferencias importantes en esta actitud (Cruz Cantero, 1988, pp. 119, 123 y 124).

\section{LAS ASOCIACIONES DE AMBITO NACIONAL}

En función de lo dicho en el apartado anterior, podría pensarse que la apatía reclamatoria y el déficit de conciencia de los españoles como sujetos de consumo, son absolutos. Y que, además, las asociaciones encarnan un 
conjunto homogéneamente endeble y mortecino, que se limita a sobrevivir. Pero las cosas no son tan así, y se aprecian gradualmente signos alentadores que indican una lenta pero firme modificación de la situación.

En 1988, las OMICs recogieron alrededor de medio millón de reclamaciones. En 1989, en una reunión celebrada en El Escorial entre empresarios y representantes de las asociaciones, voceros del INC insinuaban que, para los primeros nueve meses del año, las quejas de los consumidores contabilizables en todo el país podían estar cerca del millón, número a primera vista nada desdeñable. Los sectores que suscitaban más denuncias eran la vivienda - con un significativo porcentaje referido a los contratos de arrendamiento-y los servicios bancarios (El País, 6 de octubre de 1989, p. 34). Por otro lado, parece estar habiendo un progreso, una paulatina sofisticación, en las maneras en que el público consumidor presenta sus problemas y en los elementos que son objeto de esas presentaciones. En la Memoria 1988 de la ASGECO (p. 2) se expresaba que "... se viene notando un profundo cambio, tanto cuantitativo, como cualitativo, en las consultas y reclamaciones que se vienen recibiendo en nuestra Asociación: ... las mismas, en una gran mayoría, tienen fundamentos lógicos o con más claros planteamientos, observando que se van desplazando las problemáticas derivadas del consumo de productos o bienes básicos, hacia la utilización de servicios o adquisición de bienes duraderos".

Muchas de las reclamaciones (verbigracia, las referidas a tintorerías, lavanderías, talleres de reparación de automóviles, agencias de viaje, electrodomésticos, etc.) se procesan en las Juntas Arbitrales, un mecanismo de mediación en el que participan asociaciones de consumidores, cámaras empresariales y Administraciones Públicas, que estaba previsto en la Ley 26/1984 y que fue revalidado por la Ley de Arbitraje promulgada en 1988. Las Juntas suponen una suerte de justicia alternativa, en la que se busca la conciliación y el laudo. Menos onerosa y más rápida que la ordinaria y especialmente apropiada para solucionar conflictos como los concernientes al consumo, su consolidación depende de que cada vez más empresarios y Administraciones vayan adhiriéndose formalmente y sometiéndose a este sistema.

A partir de 1988, las asociaciones están obligadas a presentar al INC una relación según sectores de las consultas y reclamaciones que han evacuado. En el cuadro I se exponen las de ese año y el siguiente, correspondientes a la agrupación estadística hecha en el Instituto de las cifras de las siete federaciones u organizaciones nacionales. Las relaciones remitidas por las federaciones incorporan los datos de sus entidades integradas de menor grado, autonómicas y provinciales. Además de los totales, en el INC se me proporcionó la discriminación de las consultas y reclamaciones en Sanidad, separadas en Pública y Privada. Por consulta debe entenderse la simple solicitud de aclaración, explicación, consejo, etc., de un interesado, que no deriva en gestión alguna. La reclamación es un asunto en el que el 
planteo del interesado ocasiona una gestión o trámite ulterior. En ambos años el rubro que más consultas y reclamaciones motivó fue la vivienda, con más o menos la quinta parte.

\section{CUADRO I}

Consultas y reclamaciones recibidas por las organizaciones $y$ federaciones de consumidores y usuarios de ámbito nacional. Años 1988 y 1989

\begin{tabular}{|c|c|c|c|}
\hline & 1988 & 1989 & $\begin{array}{l}\text { Diferencia } \\
\quad 89 / 88\end{array}$ \\
\hline Número total de consultas & 48.833 & 134.328 & +85.495 \\
\hline Consultas en Sanidad .......... & 2.241 & 4.941 & +2.700 \\
\hline $\begin{array}{c}\text { Consultas en Sanidad sobre total de consul- } \\
\operatorname{tas}(\%)\end{array}$ & 4,6 & 3,7 & -0.9 \\
\hline 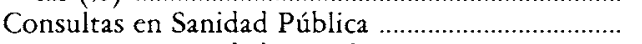 & 1.525 & 3.266 & +1.741 \\
\hline 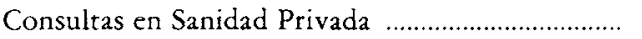 & 716 & 1.675 & +959 \\
\hline Consultas en Sanidad Pública sobre consultas & & & \\
\hline Sanidad en general $(\%)$ & 68,0 & 66,1 & $-1,9$ \\
\hline Consultas en Sanidad Privada sobre consultas & & & \\
\hline Sanidad en general $(\%)$ & 32,0 & 33,9 & $+1,9$ \\
\hline 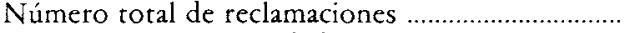 & 37.110 & 48.438 & +11.328 \\
\hline 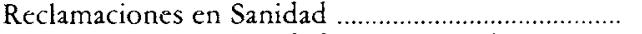 & 1.346 & 3.673 & +2.327 \\
\hline $\begin{array}{l}\text { Reclamaciones en Sanidad sobre total de reclama- } \\
\text { ciones }(\%) \text {. }\end{array}$ & 3,6 & 7,6 & $+4,0$ \\
\hline Reclamaciones en Sanidad Pública ……........................ & 916 & 1.101 & +185 \\
\hline Reclamaciones en Sanidad Privada ............................... & 430 & 2.572 & +2.142 \\
\hline $\begin{array}{l}\text { Reclamaciones en Sanidad Pública sobre reclama- } \\
\text { ciones Sanidad en general (\%) .................................. } \\
\text { Reclamaciones en Sanidad Privada sobre reclama. }\end{array}$ & 68,1 & 30,0 & $-38,1$ \\
\hline $\begin{array}{l}\text { Reclamaciones en Sanidad Privada sobre reclama- } \\
\text { ciones Sanidad en general }(\%)\end{array}$ & 31,9 & 70,0 & $+38,1$ \\
\hline
\end{tabular}

FuenTE: Elaboración propia a partir de datos del Instituro Nacional de Consumo.

El cuadro se hace acreedor a varios señalamientos. En todas las filas con números absolutos, hay aumentos de un año al otro. Sería francamente interesante ver qué ha venido ocurriendo posteriormente e ir construyendo una serie con la que verificar si se trata efectivamente de una tendencia de ascenso sostenido de la proclividad social a recurrir a las asociaciones. Las consultas totales crecen un 175 por 100 y las de Sanidad un 120 por 100 , mermando, por tanto, el peso proporcional de las segundas (de 4,6 a 3,7 por 100). No obstante, las casi 5.000 consultas por Sanidad de 1989 denotan ya una cierta envergadura. Los sectores en que se divide la relación 
que se envía al INC son nada menos que diecinueve ${ }^{3}$, esto es, un listado prolijo cuya amplitud clasificatoria necesariamente puede redundar en la dispersión de la distribución según rubros. A la luz de ese detalle, debería ponderarse aquel peso proporcional, que de entrada puede parecer restringido. Tanto en 1988 como en 1989, las consultas por Sanidad se reparten en dos tercios y un tercio para la Pública y la Privada, respectivamente. Un reparto que se acerca a los porcentajes de prestaciones - por ejemplo, de estancias y actos quirúrgicos- que atienden globalmente cada uno de estos subsectores (Instituto Nacional de Estadística y Ministerio de Sanidad y Consumo, 1990, pp. 59 y 99).

Respecto a las reclamaciones, las totales se incrementan en un 30 por 100 y las que atañen a Sanidad el 173 por 100. Ello hace más que duplicar la representación porcentual de éstas (del 3,6 al 7,6 por 100), estando por arriba de las 3.500 en 1989 . La subida responde en gran medida a que las reclamaciones inventariadas en el subsector sanitario privado se sextuplican - de 430 a más de 2.500 -, con lo cual simultáneamente hay un brusco cambio, la inversión lisa y llana, de las proporciones de la Pública y la Privada dentro del rubro en general. Esta impresionante multiplicación se debe básicamente a las cerca de 2.000 denuncias tramitadas por la FUCI contra los seguros privados de asistencia médica, una de las líneas de trabajo en que se ha especializado esa federación. Mientras que la FUCI clasifica tales denuncias en Sanidad, las restantes organizaciones a menudo lo hacen en el sector compañías de seguros. La imputación a uno u otro lugar es, por supuesto, a veces opinable, ya que la frontera entre los aspectos contractuales y los estrictamente asistenciales puede ser borrosa.

En términos generales, las reclamaciones sobre la Sanidad Pública aluden a listas de espera, trastornos y demoras en urgencias, reintegro de gastos, negligencias médicas, etc. En cuanto a la Privada, lo recién mencionado de los seguros (incumplimiento de cobertura en ciertas prestaciones, deficiencias en la atención en los centros adscritos y/o de los profesionales de sus plantillas, etc.), problemas de especialistas (por ejemplo, con estomatólogos cuya asistencia ha dejado insatisfecho al cliente), laboratorios medicinales, también presuntas malas prácticas, etc. Cuando la reclamación es relativa a la esfera público-estatal, las asociaciones se encargan de dirigir un escrito al organismo pertinente (Inspección Médica, Dirección Provincial del INSALUD, etc.), describiendo el problema y explicitando los derechos que pueden estar siendo infringidos, y se vigila el desenlace del trámite administrativo. Si la denuncia implica a una instancia privada (seguro, sanatorio, médico) se actúa en un sentido parecido y habitualmente se propone acercar las posiciones de las partes, teniendo siempre presentes los

3 Agencias de viaje, agua, alimentación, automóvil, compañías de seguros, electricidad, electrodomésticos, farmacia, gas, hostelería-restaurantes, muebles, ropa-calzado, sanidad, servicios bancarios, teléfono, tintorería, transporte público, vivienda y otros. 
legítimos intereses del consumidor que puedan haber sido dañados. En aquellos casos en los que hay claros indicios de mala praxis, tanto en centros públicos como privados, al margen de la vía administrativa, se asesora jurídicamente al interesado y se le orienta sobre la interposición de una acción ante los tribunales. En virtud de las peculiaridades del hecho, se le indica si es o no factible que prospere una demanda, querella o denuncia judicial, indicación que hacen el o los abogados que pertenecen a la entidad. Dado que estos procesos entrañan gastos (tasas, costas, fianzas, etc.) y las entidades no están en condiciones ni es su finalidad funcionar como bufetes convencionales, si el afectado se decide a entablar el contencioso, se le ofrece la alternativa de ser derivado para su representación a algún letrado allegado a la asociación, quedando obviamente a su criterio optar por él o por cualquier otro. Este es el mecanismo más extendido, pero, desde luego, hay matices y variaciones.

La Ley 26/84 contempla el denominado beneficio de justicia gratuita para las entidades de consumidores, reconociéndoles capacidad legal para personarse como parte en el ejercicio de la acción popular en juicios conectados con la problemática del consumo. Hasta 1990 muchos jueces no admitían la legitimación de las organizaciones, hasta que a mediados de ese año un Real Decreto corroboró expresamente aquella capacidad para actuar ante los tribunales de justicia en apoyo de los consumidores ("En defensa del consumidor" [Editorial], El País, 3 de julio de 1990, p. 12).

Tanto en Sanidad como en los otros rubros, el talante que predomina en las entidades de consumidores ante las reclamaciones que les llegan suele ser prudente y moderado, sin inclinarse apriorísticamente a favor del usuario. Cada caso tiene que ser estudiado y, a fin de fortalecer la confianza frente al público, empresarios y autoridades, se evita actuar temerariamente o enzarzarse en pugnas sin fundamento, que puedan devaluar la imagen y la credibilidad.

En el cuadro II se muestra la estadística de reclamaciones y consultas del año 1989 que pude recolectar en cada una de las organizaciones y federaciones de ámbito nacional. La UCE, seguida por la CECU, son las que holgadamente reciben más consultas y reclamaciones por todos los sectores.

La UCE (con 2.826) es la que, en términos absolutos, recoge sobradamente más consultas en Sanidad, siendo la segunda en cuanto al peso porcentual de éstas sobre las que recibe en todos los sectores (con 4,8 por 100). ASGECO es la primera en términos porcentuales (con el 7,3 por 100) y la segunda en números absolutos (con 1.104). Entre UCE y ASGECO captan el 80 por 100 de las consultas en Sanidad recibidas por las entidades de ámbito nacional para ese año (véase cuadro I). Acerca de la distribución de estas consultas según subsectores sanitarios, mientras en FEACCU y FUCI el cien por cien es motivado por la Pública, la UCE calca las proporciones para la agrupación estadística de las siete entidades (dos terceras partes para la Pública y una para la Privada), y en ASGECO y 


\section{CUADRO II}

Consultas y reclamaciones recibidas por las organizaciones y federaciones de consumidores y usuarios de ámbito nacional, por entidad. Año 1989

\begin{tabular}{|c|c|c|c|c|c|c|c|}
\hline & $A S G E C O$ & $C E C U$ & $F E A C C U$ & FUCI & $O C U$ & $U C E$ & $U N A E$ \\
\hline Consultas todos los sectores* & 15.101 & 40.324 & 4.664 & 5.820 & 8.019 & 59.097 & 1.308 \\
\hline 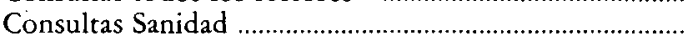 & 1.104 & 421 & 205 & 270 & 73 & 2.826 & 42 \\
\hline Consultas Sanidad sobre consultas todos los secto- & 73 & 10 & 44 & 46 & 00 & 48 & 32 \\
\hline Consultas Sanidad Pública & 6,3 & $\begin{array}{r}1,0 \\
202\end{array}$ & $\begin{array}{r}4,4 \\
205\end{array}$ & $\begin{array}{r}4,0 \\
270\end{array}$ & $\begin{array}{r}0,9 \\
61\end{array}$ & $\begin{array}{r}4,8 \\
1.889\end{array}$ & $\begin{array}{r}3,2 \\
28\end{array}$ \\
\hline Consultas Sanidad Privada & 493 & 219 & 0 & 0 & 12 & 937 & 14 \\
\hline $\begin{array}{l}\text { Consultas Sanidad Pública sobre Sanidad en gene- } \\
\text { ral (\%) }\end{array}$ & 55,3 & 48,0 & 100,0 & 100,0 & 83,6 & 66,8 & 66,6 \\
\hline $\begin{array}{l}\text { Consultas Sanidad Privada sobre Sanidad en gene- } \\
\text { ral }(\%)\end{array}$ & 44,7 & 52,0 & 0,0 & 0,0 & 164 & 33,2 & 33,3 \\
\hline Reclamaciones todos los sectores* & 4.217 & 11.440 & 7.154 & 3.862 & 2.405 & 18.622 & 534 \\
\hline 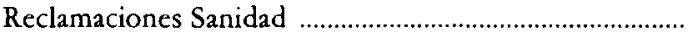 & 259 & 186 & 291 & 2.023 & 36 & 870 & 8 \\
\hline Reclamaciones Sanidad sobre reclamaciones todos & & & & & & & \\
\hline los sectores $(\%)$ & 6,1 & 1,6 & 4,1 & 52,4 & 1,5 & $4,7^{\circ}$ & 1,5 \\
\hline 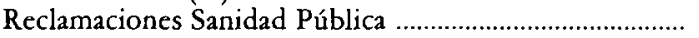 & 118 & 114 & 291 & 8 & 32 & 532 & 6 \\
\hline Reclamaciones Sanidad Privada & 141 & 72 & 0 & 2.015 & 4 & 338 & 2 \\
\hline $\begin{array}{l}\text { Reclamaciones Sanidad Pública sobre Sanidad en ge- } \\
\text { neral }(\%) \text {. }\end{array}$ & 45,6 & 61,3 & 100,0 & 0,4 & 88,9 & 61,1 & 75,0 \\
\hline neral $(\%)$ & 54,4 & 38,7 & 0,0 & 99,6 & 11,1 & 38,9 & 25,0 \\
\hline
\end{tabular}

* Según estos datos, que me fueron suministrados por las mismas asociaciones, la suma de sus consultas por todos los sectores serían 134.333 , que no coinciden exactamente con la cifra de 134.328 dada por el INC. Lo mismo ocurre con las reclamaciones por todos los sectores, que alcanzarían las 48.234 conforme a los datos recolectados en las asociaciones versus las 48.438 contabilizadas por el INC (véase cuadro I).

Para el resto de la información, la agregación de los datos de las entidades concordaría con lo recabado en el Instituto.

FUENTE: Elaboración propia a partir de los datos suministrados por las siete entidades de ámbito nacional. 
CECU proceden de la Pública algo más y algo menos de la mitad, respectivamente.

Debido a su labor en materia de seguros privados y a la imputación que ha hecho en la clasificación, la FUCI con mucha diferencia es la que ha cosechado más reclamaciones en Sanidad, las cuales representan más del 50 por 100 de las que ha tramitado en todos los sectores. En guarismos absolutos, le siguen la UCE (con 870); en porcentajes sobre todos los sectores, ASGECO (con el 6,1 por 100). La FUCI más la UCE reúnen más de las tres cuartas partes de las reclamaciones en Sanidad tramitadas por las siete asociaciones. En FUCI, prácticamente todas las reclamaciones en Sanidad aparecen en el subsector privado; en ASGECO, más de la mitad. En las otras cinco asociaciones, la mayoría - desde el 61,1 por 100 en UCE al cien por cien en FEACCU- son motivadas por la Sanidad Pública.

A continuación, voy a detenerme en la información más puntual que obtuve de las distintas asociaciones. Su profundidad y naturaleza dependen de la capacidad y las pautas diferenciales de las entidades en cuanto a su tratamiento más o menos pormenorizado, y del grado de acceso también diferencial que se me permitió a los datos.

ASGECO, que está emparentada orgánicamente con la Unión Nacional de Cooperativas de Consumidores y Usuarios de España, había realizado 1.239 actuaciones (consultas más reclamaciones) sobre Sanidad en general en 1988. En 1989, como ya mostré, se elevaron a 1.363: 1.104 consultas y 259 reclamaciones. De estas reclamaciones, 141 eran de la Sanidad Privada. Las causas de las mismas - con arreglo a la categorización propuesta por el INC en el formulario para la relación- eran el fraude en la prestación de servicios en 31 casos, el incumplimiento en las condiciones de venta en 42 y otras en 68. Esas reclamaciones sanitarias privadas se resolvieron en un 52 por 100 , se trasladaron a organismos públicos en un 32 por 100 y se archivaron en un 16 por 100.

CECU, que tiene una de sus sedes centrales en Sevilla, es una confederación creada en 1987 al aglutinarse diversas entidades de nivel autonómico y edita una revista con su nombre. Tuvo en 1989114 reclamaciones en Sanidad Pública, de las que el 20 por 100 se resolvieron, el 56 por 100 se trasladaron a organismos públicos y el 24 por 100 se archivaron. Y 72 en Privada (67 por 100 resueltas, 12 por 100 trasladadas y 21 por 100 archivadas).

FEACCU, que, como ya apunté, se origina en las antiguas Asociaciones de Amas de Casa, conserva a raíz de su génesis un perfil más tradicional y también, como tributo a estos moldes primigenios, una red con unas 600 delegaciones locales. Es la organización que declara más socios, todos ellos mujeres. En los pueblos sus entidades adheridas imparten clases de cocina, costura, gimnasia, etc., aprovechándose las instalaciones para conferencias y charlas. Se distingue de las demás asociaciones porque el cien por cien de sus actuaciones sobre Sanidad - casi 500 entre consultas y reclamaciones en 
1989- se refieren al subsector público, básicamente por anomalías en las urgencias hospitalarias y listas de espera. Es intención de sus responsables poner en marcha en el futuro inmediato un programa específico sobre Sanidad.

FUCI cuenta con 45 entidades federadas. Su trabajo en relación con los seguros médicos privados ha tenido mucho eco. Prueba de ello, las numerosísimas reclamaciones que tramitó en 1989 por denuncias de cláusulas abusivas, falta de cobertura, incumplimiento de las pólizas, etc., y que seguramente deben haberse reavivado en 1991 como consecuencia del protestado y enorme aumento que, a principios de año, las aseguradoras imprimieron a las primas, particularmente a las de las personas de la tercera edad. La estadística de esta federación revela un altísimo porcentaje de éxitos en la resolución por mediación de los conflictos entre compañías y clientes. En aquellas reclamaciones en las que la mediación no funciona y hay dos o más consumidores perjudicados por la misma causa -a los que entonces se considera un colectivo-, la política de la FUCI es personarse ante los tribunales como parte y solicitar justicia gratuita. Han gestionado algunos casos por mala praxis médica, destacándose el de un paciente asistido en su domicilio, que presuntamente fue revisado superficialmente sin que se le detectara una perforación intestinal, por la que falleció a las pocas horas. Esta federación, como asimismo la UCE, tramitaron algunas de las denuncias de los pacientes aquejados de disminución de su agudeza visual por la aplicación del colirio Colircusi. El episodio se desencadenó a fines de 1987 al descubrirse que la infección postoperatoria de una mujer intervenida de cataratas en el Hospital Clínico de Valladolid había sido producida por el empleo de dicho colirio, contaminado con Pseudomona Aeruginosa. El Centro Nacional de Farmacobiología y el propio laboratorio confirmaron posteriormente que dos lotes del producto estaban en malas condiciones por la presencia de ese microorganismo. El director general de Farmacia y Productos Sanitarios compareció ante las cámaras de televisión para informar sobre la contaminación y la conveniencia de acudir al especialista si se había utilizado el colirio infectado. El Ministerio expedientó al laboratorio y algunos pacientes le entablaron juicio. La FUCI, al momento de acopio de estos datos, continuaba actuando en respaldo de uno de ellos.

OCU, nacida en 1975, fue la primera de las entidades españolas que se constituyó pretendiendo tomar como modelo a las homólogas europeas. Por su protagonismo y activismo personal, el nombre de su fundador, Antonio García Pablos -que en 1974 ocupó la presidencia del desaparecido Consejo de Comercio Interior y de los Consumidores-, fue durante algunos años sinónimo del entonces incipiente movimiento asociativo de los consumidores en general. Al desatarse la epidemia de la colza, García Pablos asumió la representación jurídica de más de 1.300 víctimas del síndrome tóxico y creó una asociación de afectados, de la que dimitió más tarde. Tras una crisis interna de la organización, se separó de OCU a fines 
de 1981 y conformó la Asociación de Consumidores y Usuarios de España (ACUDE). En la actualidad, OCU edita dos revistas que se distribuyen por suscripción entre sus socios, Compra Maestra (con análisis comparativos de productos y servicios) y Dinero y Derechos (con información sobre servicios bancarios, actividades financieras, alquileres, etc., desde un enfoque que prioriza los intereses de usuarios y clientes). Su zona de acción se ciñe principalmente a Madrid. Con algo más de 100 actuaciones en 1989 , ostentaba el porcentaje más bajo de consultas en Sanidad y uno de los dos más reducidos de reclamaciones en ese rubro dentro de todos los sectores. Han tramitado varias presuntas malas prácticas médicas (un fallecimiento en el Hospital La Paz, una intervención de meniscos mal efectuada, una denuncia criminal y administrativa por desperfectos en una incubadora que conllevaron daños en una recién nacida, etc.). Una acotación interesante que se me formuló en las visitas que hice a OCU fue respecto al serio problema que tienen las asociaciones de consumidores para conseguir peritos médicos de parte en los que confiar técnica e institucionalmente a la hora de requerir un dictamen o una opinión sobre casos de mala praxis.

Fundada a mediados de los sesenta, UNAE es la entidad de ámbito nacional que menos consultas y reclamaciones totales ha recibido, sumando las de Sanidad solamente 50 (42 de las primeras y 8 de las segundas). De todos modos, su gabinete jurídico elaboró en 1990 dos informes sobre cuestiones sanitarias. El primero, a partir de una encuesta en ambulatorios y centros de salud de Madrid para conocer el desenvolvimiento y la acogida entre el público del programa de cita previa implementado por el INSALUD. El segundo, sobre la regulación legal de los seguros de asistencia sanitaria, a propósito del enfrentamiento entre éstos y los ginecólogos de sus cuadros médicos por las tarifas con que se retribuían sus consultas. Este informe describía la imprecisión y vaguedad de muchas pólizas; las frecuentes discrepancias por los plazos de carencia; la contratación de servicios que en la práctica no se prestan; la unilateral rescisión del contrato por parte de algunas compañías cuando consideran que los gastos que origina el usuario no las compensan económicamente; el establecimiento de topes a los médicos en la prescripción de análisis o tratamientos costosos; las controversias respecto a la declaración que hace el contratante sobre su estado de salud al formalizar el contrato, en las que a veces comete errores involuntarios que luego son abusivamente esgrimidos para denegarle ciertas prestaciones, etc.

No por azar he dejado a la UCE como última estación del recorrido puntual por estas asociaciones. La UCE es la que más se ha desarrollado en los últimos tiempos, mediante una configuración de 60 entidades y 80 oficinas que cubren todo el territorio, incluidas Ceuta y Melilla. En 1989 atrajo más del 40 por 100 de las consultas y canalizó aproximadamente el 38 por 100 de las reclamaciones para todos los sectores dentro del conjunto de las siete organizaciones nacionales examinadas. Con la clara vocación de erigirse en el referente cardinal y más representativo de la protección de los 
consumidores en España, exhibe una fisonomía vigorosa, afanándose por superar los estilos voluntaristas y artesanales de gestión a favor de patrones técnico-organizativos más modernos, y ha ganado en identificación pública merced a un hábil trabajo de contacto y divulgación con los medios de comunicación. Edita la revista Ciudadano, la de mayor tirada en su género -unos 70.000 ejemplares-, que se vende por suscripción y en los quioscos. Entre las prestaciones a los socios, descolla un seguro de defensa jurídica ante eventos en los que sus intereses como consumidores hayan sido lesionados, consistente en asesoramiento extrajudicial, reclamación de daños de origen no contractual, y defensa y reclamación amistosa y judicial, que comprende costas, honorarios y gastos de abogado, derechos de procurador, desembolsos notariales, etc., hasta un máximo de 500.000 pesetas. En ambientes del movimiento asociativo se suelen escuchar velados reproches a la UCE por su condición supuestamente oficialista y por gozar de un aparente favoritismo de parte de la Administración, dada su buena relación con la UGT y con algunos segmentos del PSOE.

Ajusta su quehacer a un esquema por programas, volcados a parcelas específicas del consumo (bancos, alimentación y nutrición, vivienda, energía, etc.). Uno de los primeros fue el de Sanidad. Y lo fue porque el bautismo de fuego de la UCE se dio precisamente a través de su intervención en una contienda sanitaria: la huelga de médicos de la primavera de 1987. En pleno auge de la misma, cuando el ala más contestataria y beligerante de los facultativos nucleada en la Coordinadora de Médicos de Hospitales la mantenía convocada con carácter indefinido, la UCE lanzó una campaña informativa sobre los derechos de los pacientes y de recepción de reclamaciones en los centros del INSALUD. Se repartieron miles de hojas de reclamaciones, con amplio impacto entre los pacientes que empezaron a hacer llegar sus protestas porque se les negaba o dilataba la asistencia o porque eran objeto de un trato destemplado por parte del personal médico. La UCE fue ordenando y trasladando las reclamaciones al INSALUD, instándolo a resolver los casos con prontitud y de manera acorde a los intereses de los usuarios. Mediante este engranaje, se agilizó y regularizó el reintegro de gastos a muchos pacientes que, por estar obstaculizada su atención en los hospitales públicos, no habían tenido más remedio que hacerse análisis u operarse en centros privados. Pero otros casos de esa época revistieron mayor gravedad y terminaron en los tribunales. El 27 de mayo, una mujer y un hombre jóvenes, luego de ser atropellados por un coche, fueron llevados por la Policía al Hospital Clínico de Madrid, en el momento en que se celebraba una asamblea. Tras esperar una hora y media en la guardia, se les hicieron radiografías y se les escayoló. A pesar de que acusaban mareos y dolores, se les obligó a vestirse y abandonar el centro. Ante su resistencia, según la versión de los pacientes, un médico les replicó que "no se encontraban en un hotel". A las dos horas de volver a su casa, la joven debió ser conducida a una clínica privada, apreciándosele lesiones en las vértebras 
cervicales. Los servicios jurídicos de la UCE radicaron denuncia del hecho en un juzgado. El 5 de junio aparecía en la primera plana de El País la foto de la mujer, postrada en su domicilio, con muletas, escayola y minerva. En el pie de la foto se censuraba el "inhumano trato" dispensado en el Clínico. Mientras tanto, en el marco de una situación de absoluta anormalidad por la huelga, el 7 de junio fallecía en el Hospital Marqués de Valdecilla, de Santander, un hombre de 60 años, víctima de hemorragias digestivas, después de permanecer ingresado durante cuatro días, sin que -amén de otros yerros y omisiones - se le pusiera una vía central, tal como, aparentemente, imponían las circunstancias. Desde el punto de vista de la familia, para el fatal desenlace habían concurrido la dejación de los adjuntos y la falta de formación de los MIR para tomar a su cargo el enfermo. El suceso, de aristas muy complejas en virtud de la implicación de un gran número de personas, fue investigado administrativamente por el INSALUD, dando lugar a una información reservada con conclusiones bastante lapidarias en cuanto a la asistencia prestada. Más tarde, con el apoyo de abogados cercanos a la Asociación de Consumidores de Cantabria (integrada a la UCE), pasó a jurisdicción penal, llamándose a declarar a más de quince profesionales sanitarios, entre médicos y ATS. A fines de 1988 el juez decretó el archivo de las diligencias, sin perjuicio de la acción civil que ulteriormente se emprendió y cuyo procedimiento continuaba.

A lo largo de la huelga, la UCE desplegó otras actividades. Se entrevistó con el entonces Defensor del Pueblo, Joaquín Ruiz-Giménez; participó en un debate con partidos políticos, sindicatos y colectivos médicos, llevado a cabo en el Consejo General de Colegios Oficiales de Médicos (CGCOM), y aprovechó el espacio que le brindaba la prensa. La organización calificó de "auténtico terrorismo médico" las intimidaciones y amenazas con las que algunos facultativos arrostraban a los pacientes que se quejaban de la irregular atención de aquellos días, y achacó a la Coordinadora de Médicos de Hospitales la persistencia del conflicto por la ambición de conservar privilegios profesionales y corporativos (El País, 27 y 30 de mayo de 1987, p. 28). Por su parte, Luis Cabañas, presidente de la Coordinadora, salió al paso, afirmando que "el PSOE y la Administración han tenido que sacar una organización de consumidores, que es de ellos, para perseguir a los médicos de hospitales" (El País, 8 de junio de 1987, p. 33).

De aquel conflicto la UCE extrajo una rica experiencia, que se tradujo en el diseño de su programa sectorial. En 1988 se tramitaron 765 reclamaciones en Sanidad. En 1989, 870, de las cuales el 56 por 100 tuvieron una solución favorable, el 28 por 100 seguía en trámite y el 16 por 100 se archivaron. Según la clasificación estadística interna de la organización, una quinta parte era atribuible a listas de espera, falta de información del proceso clínico, trato deshumanizado, servicios deficientes (en cuanto a comida, instalaciones, higiene, etc.) y precios de los certificados médicos.

En relación a esto último, el artículo 10, punto 8, de la Ley General de 
Sanidad (14/86, de 25 de abril) reconoce como derecho de "todos con respecto a las distintas administraciones públicas sanitarias» el que se extienda certificado acreditativo del estado de salud, cuando su exigencia se establezca por una disposición legal o reglamentaria. Pero en los artículos 58 y 59 de los Estatutos Generales de la Organización Médica Colegial (OMC) y del CGCOM, aprobados por R. D. 1018/80, se determina que ese Consejo es el único organismo autorizado para editar y distribuir los impresos de los certificados médicos oficiales, correspondiéndole fijar las clases de certificados, su importe y actualización (la recaudación de estos importes es una de las fuentes de financiación más importantes de la $\mathrm{OMC}$ ). De acuerdo al artículo 60, la "expedición" de los certificados por parte de los médicos es gratuita, aunque éstos puedan percibir honorarios, "cuando proceda", por los actos médicos que tengan que efectuar para extenderlos. En consecuencia, esos Estatutos distinguirían entre el impreso, que - salvo para las personas inscritas en los padrones de Beneficencia - tiene un precio; la expedición en sí misma, que es gratuita, y los actos médicos inherentes a la extensión del certificado, que pueden o no ser cobrados. En febrero de 1984, el Consejo de Estado dictaminó la ilegalidad de un aumento de más del cien por cien en el precio de los impresos para los certificados de aptitud para conductores de vehículos, que había adoptado la Asamblea General del CGCOM el año anterior. El 19 de octubre de 1987, la Sala Cuarta (de lo Contencioso-Administrativo) del Tribunal Supremo se pronunció acerca de que el CGCOM era incompetente para modificar las tarifas de los derechos de reconocimiento e impresos respectivos sin la correspondiente autorización administrativa, esto es, ministerial. El 4 de enero de 1989, El País (p. 22) se hacía eco de una denuncia de la Federación de Asociaciones para la Defensa de la Sanidad Pública ante el Ministerio de Sanidad y el Defensor del Pueblo, por una subida del 900 por 100 en el precio de los certificados ordinarios - de 200 a 2.000 pesetas - y de defunción - de 300 a 3.000 -, impuesta por los Colegios de León, Navarra, Cantabria y Zaragoza.

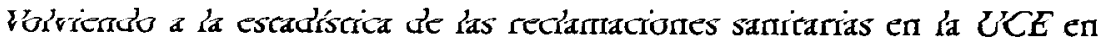
1989, hay que subrayar que la razón modal de las mismas son las negligencias médicas. Nada menos que 8 de cada 10 eran encuadradas en esta causa. De ellas, aproximadamente el 37 por 100 tenían que ver con errores.de diagnóstico (desaciertos al diagnosticar enfermedacies con graves efectos para el paciente, al que se aplica un tratamiento incorrecto), el 44 por 100 con negligencias en intervenciones quirúrgicas (olvidos de material quirúrgico en el cuerpo del operado, confusión de informes, operaciones mal hechas, decisiones no ronsultadas con el paciente ni con su familia, etc.), y el 19 por 100 con errores en la medicación (contagio de enfermedades por transfusiones, medicación inadecuada, fallos en las dosis, prescripciones sin pruebas previas para descartar alergias o incompatibilidades, etc.).

¿Qué ha venido sucediendo en los últimos años respecto a las reclama- 
ciones de los consumidores sanitarios? ¿Se percibe algún cambio en la conciencia de los mismos sobre sus derechos? ¿A qué clases sociales pertenecen los que reclaman? ¿Cuál es la respuesta de la Administración cuando se piden explicaciones sobre una presunta mala práctica en los centros públicos? Transcribo textualmente las impresiones de uno de los miembros de la UCE que se ocupan del problema de Sanidad, con quien mantuve entrevistas de cuya grabación selecciono estas citas:

"Todavía no hay dinámica de reclamación en nuestro país. Recién ahora se empieza a reclamar. Y se empieza porque se empiezan a ver vías de solución, que antes de hecho no existían. A la gente le pasaba algo y o bien se le pasaba por la cabeza coger una escopeta y "cargarse" al médico, o bien no pasaba nada. A nadie se le ocurría pedir el libro de reclamaciones, porque se sabía que nadie le iba a ayudar. Lo que hay que valorar es que ahora, poco a poco, ya empieza a haber hábito de reclamación en el usuario. Ya no se conforma con lo que le dan, sino que exige derechos si son vulnerados... Yo diría que el perfil del reclamante suele ser una clase media-baja y media-media. Estaría por ahí. La clase alta y la media-alta normalmente van a servicios privados, o salen del país si es un problema muy "gordo". Si hay que pedir reparaciones, van en general por otro lado. Y la clase baja, por así llamarla, no tiene nivel de protesta, no tiene recurso cultural y se entrega. Van al hospital completamente apabullados. Salir de su medio, ya es un trauma fuerte. No tienen nivel para preguntar, para cuestionar. Si se comete un error o una negligencia fuerte, se le dice que es un paro cardíaco y Santas Pascuas... El primer paso que se da desde aquí es solicitar un informe al INSALUD, si es un hospital adscrito al INSALUD. Te mandan una valoración del caso, que casi siempre, te digo la verdad, no suele ser favorable al usuario. Te dan todo tipo de explicaciones, que lo sienten mucho y tal. Pero lo que pasa es que muchas veces los mismos contra los que va la reclamación, son los que te dan la valoración. Y después, el corporativismo, que va desde la institución hasta el Colegio de Médicos. Encuentras unos problemas increíbles para conseguir una valoración, desde nuestro punto de vista, objetiva. Tiene que ser una reclamación muy escandalosa, muy pero muy evidente..."

A fin de familiarizarme y tener un acercamiento más vívido sobre los asuntos que se tramitan, en la UCE se me permitió el acceso a expedientes, correspondientes a reclamaciones presentadas directamente en sus oficinas centrales o que por su complejidad y singularidad necesitan de la gestión conjunta de las entidades provinciales o autonómicas con la organización central. Posteriormente, se me autorizó a lo mismo en la Unión de Consumidores de Madrid (UCM), la entidad que forma parte de la UCE en el 
nivel de esa Comunidad. De este modo, revisé unos 80 expedientes, muchos de ellos sobre reclamaciones ya solucionadas o archivadas. Entre las que continuaban en trámite, aludiré a dos de ellas que por sus características me parecen interesantes para ilustrar la casuística.

El primer caso es el de un matrimonio con tres hijos, cuya precaria situación económica los decide a buscar un medio radical y seguro para no aumentar la prole. Por recomendaciones de los vecinos, visitan a un médico particular que les aconseja una vasectomía, dándoles garantías de su eficacia. El hombre es sometido a la operación. A los noventa días se le hace el espermograma, observándose azoospermia. A la vista de tales resultados, el médico les dice que pueden reanudar las relaciones sexuales plenas. Al mes siguiente, ante su propio desconcierto, el de su esposo y el del vecindario, la mujer queda embarazada, repitiéndose entonces el espermograma, que arroja valores -4 millones de espermatozoides por centímetro cúbicomuy distintos a los del primer análisis. La pareja tuvo finalmente su cuarto hijo y, a través de un abogado allegado a la UCE, interpusieron una demanda contra el médico, los analistas y sus respectivas compañías de seguro.

El segundo caso es el de un niño de 12 años con leve retraso psíquico que, con fuertes dolores en los testículos y vómitos, acude al servicio de urgencias de un hospital público del este de Madrid. Atendido primero por un pediatra y luego por un urólogo, que se limitan a palparlo sin ninguna otra prueba, se le diagnostica epididimitis, se le receta un antiinflamatorio y aspirinas y se le remite al médico de cabecera. A la semana, como los dolores no cedían y se notaba tumefacción, vuelve a ir al hospital, punzándosele uno de los testículos y extirpándosele el otro, ante el infarto hemorrágico testicular causado por una torsión, cuadro muy frecuente en esas edades, no estimado en la primera oportunidad. Los padres fueron a la UCE, que los ayudó a obtener los informes clínicos y a hacer la denuncia ante un juzgado.

Hubo una coyuntura político-sanitaria en la que la UCM - habría que decir, más bien, su entonces presidente- jugó un papel de primera línea. A la semana siguiente que el Defensor del Pueblo hiciera público su recordado informe sobre la atención de las urgencias en la Sanidad Pública ${ }^{4}$, esta entidad saltó a la palestra dando a conocer su recuento de reclamaciones en 1988 y en lo que iba del año que estaba comenzando Con el título de «En los once primeros días de enero se han recibido 50 reclamaciones contra los hospitales madrileños", El País (12 de enero de 1989, p. 20) reseñaba algunos de los casos más aparatosos sobre negligencias médicas (una paciente

4 En los últimos meses de 1988, los asesores del Alto Comisionado de las Cortes Generales hicieron una investigación en 17 hospitales públicos y 4 Servicios Especiales de Urgen. cia. Sus conclusiones hablaban de masificación, inexistencia de camas libres y, en 10 de los hospitales, deficiencias en las instalaciones. Según el documento, la excesiva presión sobre las urgencias provenía de la inoperancia de la atención primaria y de distorsiones en la actividad hospitalaria programada (Defensor del Pueblo, 1988, pp. 91 a 104). 
que había sufrido quemaduras por un tratamiento con rayos ultravioletas, obstrucciones ureterales en dos mujeres como consecuencia de sendas operaciones de mioma, un hombre con dolores y pérdida de fuerza en la mano derecha que terminó siendo operado de su pie izquierdo, etc.). El presidente de la entidad criticaba al Colegio de Médicos por tardar más de nueve meses en pronunciarse sobre las denuncias que se le presentaban y en hacerlo sistemáticamente a favor de los galenos. El domingo 15 de enero, a doble página (24 y 25), El País volvía a la carga con un extenso reportaje - "El riesgo de acudir al hospital. Miles de madrileños sufren en su carne las consecuencias de errores médicos"-, en el que se desmenuzaban y ampliaban los datos provistos por la UCM, con declaraciones de enfermos, médicos, jefes de servịcio y directivos hospitalarios. Se apuntaba que el presidente de la UCM y el del Colegio profesional habían arribado a un compromiso y que, a partir de entonces, la primera remitiría periódicamente al segundo las reclamaciones que le llegaran. El documento del ombudsman más el escalofriante cuadro pintado por la prensa al difundir las denuncias de la UCM, crearon la sensación de un verdadero "caos sanitario" en la región madrileña, caos que condujo al relevo del director provincial del INSALUD. El cese, según el presidente de la UCM, era "la forma que utiliza el ministro de Sanidad para echar balones fuera de su departamento" (El País, 17 de enero de 1989, p. 21). Las reverberaciones del aldabonazo dado sobre las percepciones públicas acerca de la Sanidad y los médicos, no se aquietaron hasta varias semanas después. A lo largo de ese período, las páginas de los diarios se llenaron de misivas, réplicas y contrarréplicas, de pacientes, facultativos, portavoces de instituciones oficiales y de sanatorios privados, a propósito de las anomalías y los fallos médico-sanitarios. El comportamiento del titular de la UCM disgustó profundamente a la UCE y a sus entidades federadas. Por un lado, no se compartía en absoluto la modalidad desmesurada y ligera con que había manejado las reclamaciones ante la prensa; como así tampoco el tono exageradamente agresivo empleado contra la Administración. Por otro, no se estaba de acuerdo con la actitud zigzagueante frente al Colegio de Médicos y mucho menos con la decisión de entregarle las reclamaciones, dado el fundado recelo que se abriga respecto a la parcialidad de la corporación a la hora de depurar la responsabilidad de los profesionales (El País, 21 de enero de 1989, p. 23). A la postre, por esta y otras desavenencias, el presidente de la UCM fue apartado de su cargo, normalizándose la situación de la entidad en el segundo semestre del año.

Otra de las entidades integradas, la Unión de Consumidores de Aragón (UCA), también alcanzó notoriedad periodística por su labor, pero en esta ocasión no sólo contó con el absoluto apoyo de la UCE, sino que además su denuncia tuvo que ser inmediata y positivamente aceptada por las autoridades y la justicia. La UCA recibió reclamaciones de algunos consumidores con motivo de los dudosos tratamientos prestados por un fantasmagó- 
rico Instituto de Orientación, Diagnóstico y Terapéutica (INAODYT). Este Instituto hacía publicidad subrepticiamente, tratando de atraer a enfermos terminales y con pronóstico desesperanzador. Con sede en Madrid, a través de consultas volantes a cargo de médicos titulados, operaba en distintas capitales de provincia, of reciendo como medio de "diagnóstico fundamental" el llamado "examen bio-hematológico", consistente en extraer una gota de sangre del lóbulo de la oreja y descifrar a los cinco minutos la patología y la dolencia. A los enfermos se les vendían estrambóticos remedios como el "Líquido Fowler-Solución" (cuyo análisis posterior en el Departamento de Farmacología Clínica de la Universidad de Zaragoza mostró que contenía arsénico y podía tener efectos vasodilatadores y eventualmente tóxicos) y la "Solución Vínica", un desinfectante a base de limón, eucalipto y esencia de trementina. Los dos principios sobre los que, según rezaban los folletos de propaganda, se asentaba la terapéutica eran el "universalista de la integridad conservable" y el "simplista de la separatividad resolutoria". Las consultas se cobraban entre 25.000 y 30.000 pesetas y no se daban recibos. El Ministerio de Sanidad abrió expedientes por elaboración de especialidades sin registrar y fabricación de productos farmacéuticos en instalaciones sin autorización. Un juzgado de Zaragoza encausó a dos médicos, un ATS y a un abogado, cabeza visible del tenebroso Instituto, por un delito contra la salud pública. La UCA se personó en el juicio, querellańdose además por falsificación documetal y estafa (El País, 24 de noviembre y 7 de diciembre de 1989,2 y 3 de enero y 24 de marzo de 1990 , pp. 36, 30, 31, 20 y 32, respectivamente).

Termino este apartado recordando que, al margen de su función de recibir y tramitar consultas y reclamaciones, las asociaciones de consumidores tienen en el campo de la Sanidad la facultad formal de desempeñarse en otros menesteres. El Real Decreto 521/87, de 15 de abril (Reglamento sobre Estructura, Organización y Funcionamiento de los Hospitales del INSALUD), prevé la existencia de una Comisión de Participación Hospitalaria (arts. 19 y 20) y otra de Bienestar Social (art. 23). La primera es un "órgano de participación comunitaria en la planificación, control y evaluación de la gestión y de la calidad de la asistencia", correspondiéndole, entre otros cometidos, conocer y elaborar propuestas sobre los planes económicos para cada ejercicio. La segunda es un "órgano colegiado de asesoramiento al Director Gerente del hospital y a la Comisión de Participación Hospitalaria", que debe velar por el bienestar y atención general al paciente, y analizar la información recogida por el Servicio de Atención al Paciente y aquellos aspectos que puedan mejorar la asistencia (dietas alimenticias, hostelería, visitas de familiares, encuestas de hospitalización, etc). En la composición de ambas Comisiones tiene que haber dos representantes de las asociaciones de consumidores y usuarios constituidas en el Area de Salud. El Decreto señala que, al año, la de Participación Hospitalaria se 
reunirá cuatro veces en sesiôn ordinaria, y la de Bienestar Social, "como mínimo", seis veces.

La realidad ha estado bastante alejada de las previsiones normativas. Según los Indicadores de actividad bospitalaria de 1989, las Comisiones de Participación estaban conformadas en poco más de la mitad de los establecimientos, y de 50 centros donde funcionaban, en 37 no se había satisfecho el umbral de sesiones fijado en el Reglamento. Las de Bienestar estaban instauradas en algo menos del 30 por 100, y de 27 hospitales en los que habían trabajado, sólo en 3 se había cumplido o rebasado la frecuencia anual mínima de reuniones preceptuada (INSALUD, 1990, pp. 19, 33 y 35). En una entrevista que realicé a un alto cargo de la Subdirección General de Asistencia Especializada del INSALUD, éste señalaba que en muchos lugares el obstáculo más serio para la constitución y el normal desenvolvimiento de estas Comisiones estribaba en la indefinición y el desacuerdo entre las asociaciones de consumidores sobre el nombramiento de sus representantes. Con todo, en ninguna de las entidades visitadas se hizo alusión o mención, directa o indirecta, respecto a este extremo. Por el contrario, podría hipotetizarse que acaso una de las causas de la parálisis de tales Comisiones es una cierta resistencia, pasividad o desinterés, de parte de los elencos directivos de los hospitales, a ponerlas efectiva y plenamente en marcha, ya que ello podría significar una alteración no deseada en los mecanismos de decisión y un control desde instancias externas a las instituciones.

Otro espacio en el que está contemplada la participación de las asociaciones es el de los Consejos de Salud de Area, órganos colegiados para la consulta y el seguimiento de la gestión. Conforme al modelo estipulado en la Ley General de Sanidad (arts. 56 a 69), las Areas son las demarcaciones geográficas en que se divide, descentraliza y autonomiza la atención sanitaria en el Sistema Nacional de Salud. En 1990, el INSALUD reorganizó en esta línea sus servicios periféricos no transferidos a las Comunidades Autónomas, con lo cual se suprimirán las Direcciones Provinciales y se crearán las Direcciones Territoriales por Autonomía que coordinarán a las Areas de Salud.

\section{LA COORDINADORA D'USUARIS DE LA SANITAT}

Junto a las entidades que actúan abarcando potencialmente la totalidad o gran parte de los rubros del consumo, hay otras que ex profeso se circunscriben a uno de ellos. Por ejemplo, a la Sanidad. En los Estados Unidos, a comienzos de los setenta, Ralph Nader - un conocido dirigente del movimiento pro consumidores, que ya había alcanzado popularidad por su confrontación con la industria automotriz- creó el Public Citizen Health Research Group. El grupo, dedicado a la investigación y difusión, ha llevado 
a cabo campañas sobre nutrición, cirugías innecesarias, salud ocupacional, costes de la atención médica, etc., y ha sido convocado en numerosas oportunidades por las comisiones del Congréso para conocer sus posturas. En aquel país también surgió la Consumer Coalition for Health, en la que convergieron núcleos locales que luchaban por mejorar el poder relativo de los usuarios de la Sanidad (Hamilton, 1982, pp. 153 a 155).

En España existen colectivos organizados de enfermos o padres de enfermos afectados por determinadas patologías crónicas o congénitas (renales, hemofílicos, diabéticos, minusválidos psíquicos, espina bífida, etc.). Puede señalarse asimismo a la Fraternidad Cristiana de Enfermos y Minusválidos. Sus reivindicaciones apuntan centralmente al acceso a ciertas prestaciones en condiciones adecuadas y a la adopción de medidas que mitiguen sus bandicaps laborales, educativos, etc. La membrecía a los mismos, sus fines e intereses, están definidos por el padecimiento de una patología, que es el eje de su identidad. La labor de estos colectivos es indudablemente meritoria, pero, conceptualmente hablando, no puede considerárselos asociaciones de consumidores. Una asociación de consumidores y usuarios sanitarios se define (o, al menos teóricamente, debería definirse) a partir del designio de ejercer algún tipo de influencia, corrección y control sobre el mercado y los servicios médico-sanitarios en general. Su especificidad está dada por proteger los derechos de los consumidores y usuarios de la Sanidad y, por tanto, intrínsecamente, también los de quienes son o han sido enfermos o pacientes, pero sin distinción de patologías.

Cabe, además, otra precisión conceptual. Siguiendo de nuevo a Hamilton ( $I b$., Pp. 6 a 8), la gente que recibe cuidado o atención - los pacientes - son consumidores, pero no todos los consumidores o usuarios de atención médica son siempre pacientes. El ser paciente implica la interacción física y directa con el sistema sanitario en un momento dado. La noción de consumidor es, en cambio, lo suficientemente abstracta como para describir la relación de la gente con el sistema sanitario en un gran abanico de situaciones. Connota la relación del sujeto con ese sistema, sea que esté sano o enfermo y que goce del beneficio de la asistencia de un médico o que esté privado del mismo.

E1 artículo 92.1 de la Ley General de Sanidad dice que: "La Administración Sanitaria facilitará la libre actividad de las Asociaciones de usuarios de la Sanidad, de las Entidades sin ánimo de lucro y Cooperativas de tipo sanitario, propiciando su actuación coordinada con el sistema sanitario público" (mía la cursiva). Adelantándose varios años a esta ley, Carme Serarols, una educadora de enseñanza especial, impulsó la creación en 1977 de la Coordinadora d'Usuaris de la Sanitat (CUS), una entidad precursora que, por su know bow, activismo y seriedad, ha acumulado un sólido prestigio dentro y fuera del movimiento asociativo. Casi única en su especie dentro de España ${ }^{5}$, tiene su

$\checkmark$ En Oviedo también hay una asociación de características más o menos parecidas, la de Usuarios de la Sanidad Pública y Privada de Asturias. 
sede en Barcelona y su ámbito territorial de acción es Cataluña y Baleares. El otro sector en el que trabaja es el de los Servicios Sociales.

Entre los objetivos que declara la CUS, están contribuir a la ayuda moral y física de todos los afectados por cualquier enfermedad o por sus consecuencias, promover y participar en aquellas iniciativas tendentes al progreso de la salud y la atención sanitaria, desempeñar la defensa del usuario de los servicios de la Sanidad mediante la interposición de todas aquellas acciones que se estimen eficaces y sean acordes con el ordenamiento jurídico, propulsar la eduación sanitaria, sensibilizar a la opinión pública sobre la problemática y las alternativas de la Sanidad, etc.

Desde 1978 la CUS está inscrita en el Registro de Asociaciones de la Generalitat. Para su sostén cuenta con subvenciones de este organismo y del Ayuntamiento de la Ciudad Condal. En abril de 1990 instituyó el cobro de una cuota a los socios, de 1.500 pesetas anuales, que sigue siendo gratuita para las personas sin medios económicos.

La CUS informa y asesora jurídicamente, estando ligados a ella abogados especializados en Sanidad a los cuales pueden recurrir los usuarios y ser representados ante los Tribunales por honorarios más módicos que los habituales. Una de las ventajas de la entidad es que entre sus miembros hay médicos, que pueden ser consultados en relación a diagnósticos o tratamientos presuntamente erróneos y realizar peritajes.

Expondré resultados de un estudio hecho en la entidad sobre una muestra de 104 casos tomados al azar entre todas las fichas abiertas en el período que va del 1 de mayo de 1989 al 30 de abril de $1990^{6}$. Aquí se denomina "caso" a cada una de las consultas o quejas recibidas, las cuales dan lugar a la apertura de una ficha en la que, en virtud de un cuestionario, se consigna información acerca del asunto.

En cuanto al sexo de las personas afectadas por el hecho que había motivado el contacto con la CUS, 59,5 por 100 eran mujeres y 40,5 por 100 varones. La edad media de las primeras era 49 años, y la de los segundos, 39 (el cálculo en esta variable se había efectuado sobre 94 casos, sin incluir a los fallecidos, que eran 10). Dos de cada tres de los afectados residían en la ciudad de Barcelona. Casi el 40 por 100 eran pensionistas; 12,5 por 100 , estudiantes; casi el 10 por 100, amas de casa; repartiéndose el resto en ocupaciones comerciales y de servicio, industria, enseñanza, etc., y un 5 por 100 de niños todavía sin escolarizar. Las procedencias de los casos -o sea, desde dónde o quién se había aconsejado acudir a la CUS o había sido la fuente de aviso de su existencia - eran ciertamente dispersas, lo cual puede ser interpretado como un indicio de que la entidad es vista como un referente recomendable por un amplio arco de ciudadanos, profesionales, colectivos e instituciones catalanas: con sendas proporciones en torno al 10 por 100 , socios y ex casos, OMIC, medios de comunicación,

6 El trabajo fue preparado por Mercè Cruells i Salla, asesora médica de la CUS. 
Servicios Sociales del Ayuntamiento y asociaciones de consumidores; con valores en torno al 5 por 100 para cada categoría, asistentes sociales, abogados, personal sanitario, Información y Oficinas de Bienestar Social de la Generalitat e Instituto Catalán de Consumo y otras; con el 2 por 100 en conjunto, la Consejería de Sanidad y el Instituto Catalán de la Salud (ICS). En el 17,3 por 100 no constaba la procedencia.

En el cuadro III aparece la distribución de los casos según el denunciante, categorizado de acuerdo a su vínculo con el afectado. En algo más de la tercera parte, el problema fue planteado por el propio afectado, habiendo otras tres categorías con más del 10 por 100 cada una, que, obviamente, corresponden a las personas que cohabitaban con éste o que están más íntimamente emparentados (padres, hijos y cónyuges).

\section{CUADRO III}

Distribución porcentual de una muestra de quejas o consultas a la CUS, según denunciante.

Mayo de 1989 a abril de 1990

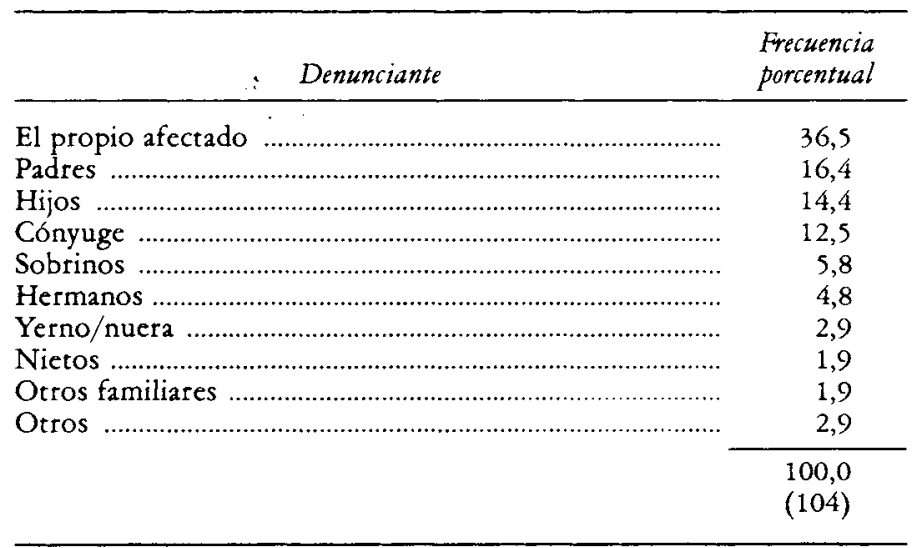

FuENTE: Coordinadora d'Usuaris de la Sanitat.

Entre los denunciantes volvía a haber exactamente como antes, un 59 por 100 de mujeres y in 40,5 por 100 de hombres. Las causas por las que Se habían formulado las quejas o consultas se exhiben en el cuadro IV.

La causa más frecuente, con un tercio de los casos, eran presuntos errores cometidos en actos médico-asistenciales. Si a ello se le suma la mala 


\section{CUADRO IV}

Distribución porcentual de una muestra de quejas o consultas a la CUS, según causa del caso. Mayo de 1989 a abril de 1990

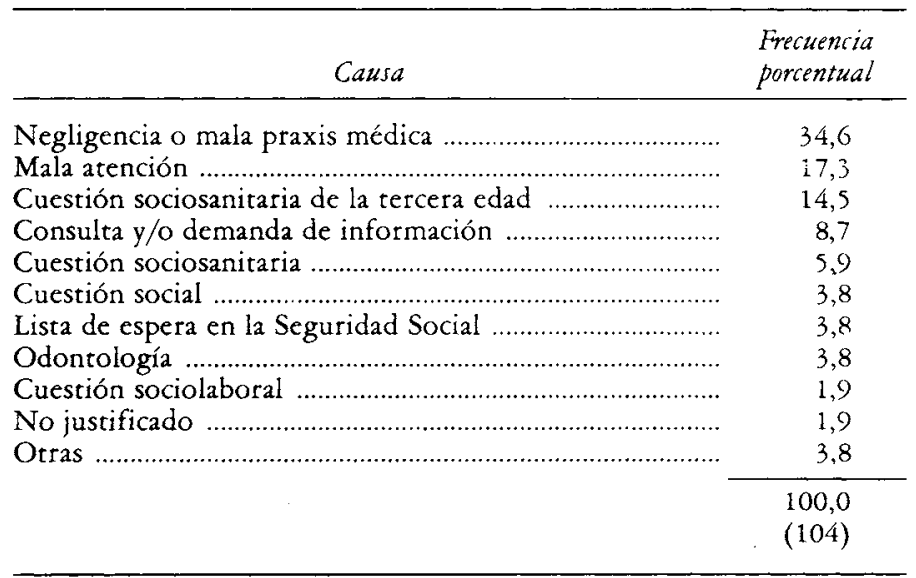

Fuente: Coordinadora d'Usuaris de la Sanitat.

atención, se tendría que algo más de la mitad de estas denuncias está ocasionada por anomalías en la forma y/o el contenido de las prestaciones sanitarias. El tercer motivo en orden de importancia eran cuestiones acerca de la atención sociosanitaria de ancianos.

¿De qué manera se había actuado frente a estas quejas y consultas? En el 45,2 por 100, la CUS hizo trámites - llamadas telefónicas, cartas, etc.ante las Administraciones, el ICS y el Instituto Catalán de Asistencia y Servicios Sociales. En el 24 por 100 se indicó a los consultantes los trámites que debían realizar o a facilitarles información. Algo más de la quinta parte había sido enviado a un abogado. Y había un 8,7 por 100 en que se estaba a la espera de la decisión de los denunciantes. Finalmente, un 76 por 100 de los casos permanecía abierto, mientras el 24 por 100 ya había sido archivado.

La CUS cumplió un rol fundamental en el sonado caso de la residencia geriátrica Alba, un episodio que destapó la necesidad de reforzar la supervisión de las estructuras de asistencia y acogida a la población de la tercera edad. El 21 de septiembre de 1989, después de que trabajadoras de ese centro privado - sito en la carletera de Vallvidrera - entregaran datos y fotos a la Coordinadora que patentizaban las penosas condiciones de alojamiento y el abandono de muchas residentes, la entidad presentó una denuncia ante la fiscalía de la Audiencia de Barcelona. En la madrugada del 22, una comi- 
sión judicial fue a la residencia y descubrió un cobertizo, aislado de las dependencias centrales, en que estaban hacinadas ancianas. En el lugar, un barracón con 10 camas en una superficie de 20 metros cuadrados, hallaron restos de comida, excrementos, insectos y a las mujeres con señales de desnutrición y úlceras de decúbito. Estas residentes, con demencia senil, eran habitualmente encerradas con llave entre las 19,00 de la tarde y las 7,00 de la mañana siguiente. A otras se las había encontrado instaladas en un cuarto de leña y en un vestidor. Ese mismo día, el titular del Juzgado de Instrucción número 18 ordenó el ingreso en prisión de la directora y, a la vez, propietaria, el traslado de 15 ancianas al Instituto Frenopático y el cierre de la residencia. El 25 prestó declaración el médico encargado de visitar a las internas una vez a la semana, siendo interrogado sobre el fallecimiento de una de ellas ocurrido un día antes de radicarse la denuncia. El médico, que había certificado como causa de muerte un accidente vascular cerebral, admitió que lo había extendido sin reconocer el cadáver, no haciendo constar la caquexia que observaron los forenses al exhumarlo. El facultativo fue conducido a prisión, y su foto, bajando las escalinatas del Juzgado, esposado y rodeado de policías, provocó un hondo impacto en la opinión pública catalana, y muy especialmente en los medios profesionales. La directora general de Servicios Sociales de la Generalitat calificó de "precipitado y sin justificación" el traslado de las ancianas, desobedeciendo inicialmente la orden judicial de cierre del establecimiento y haciendo saber que inspectores de ese organismo lo habían visitado el lunes anterior al estallido del escándalo sin notar nada anormal (El País, 24 y 26 de septiembre de 1989, pp. 23 y 28, respectivamente). El 28, en una conferencia de prensa, el presidente de la Generalitat y el consejero de Bienestar Social declinaron cualquier responsabilidad directa de ese departamento autonómico, dado que el geriátrico era un centro privado no subvencionado. Entretanto, el Colegio de Médicos de Barcelona salió virulentamente en defensa del médico encarcelado. En un comunicado, que implícitamente ponía en entredicho la solvencia e imparcialidad de la justicia ordinaria, pedía "la inmediata constitución de una comisión de expertos elegidos por sus méritos y conocimientos" para explorar a las pacientes y "obtener conclusiones científicas con garantías". "Estamos aterrorizados - declaraba el presidente colegial- por la presión a que somos sometidos en nuestros juicios de diagnóstico por colectivos que no tienen elementos para valorarlosn, y hacía un llamamiento a sus colegas para que en adelante practicaran una medicina defensiva: "no firmar ningún certificado de defunción que no tenga una base objetivable que luego pueda ser demostrada ante el juez" (El País, 30 de septiembre de 1989, p. 30). "Preocupados, los médicos de otros centros geriátricos [catalanes] se han apresurado a enviar a todos sus pacientes a los hospitales para que verificaran su estado de salud" (Diario 16, 2 de octubre de 1989, p. 30). Ocho familiares de otras tantas residentes y la CUS intepusieron una querella contra la propietaria y el galeno por el fallecimiento de otra anciana 
acaecido en abril. Quince días después de que sus hijas la retiraran del centro, esta mujer había muerto por una infección generalizada, sobrevenida, aparentemente, por no haberle sido debidamente curadas en el geriátrico las llagas y ulceraciones que padecía. El fiscal solicitó el procesamiento de los acusados. Los cargos contra la directora eran estafa, falsedad en documento, usurpación de funciones y omisión del deber de socorro, delito este último del que también era inculpado el médico, amén del de imprudencia temeraria (El País, 13 de diciembre de 1989 y 22 de mayo de 1990, pp. 33 y 28, respectivamente). El Defensor del Pueblo, como producto de una investigación llevada a cabo por sus asesores en distintas regiones, remitió al Ministerio de Asuntos Sociales y a los presidentes de las Comunidades Autónomas una "Recomendación sobre las residencias privadas y públicas de la tercera edad». En ese documento se enfatizaba en la urgencia de controlar y regular normativamente el funcionamiento de las residencias privadas de ancianos en España, las cuales poseen casi un 80 por 100 de las plazas ofertadas (El País, 30 de diciembre de 1989, p. 26).

\section{REFLEXIONES FINALES}

A la vista de la descripción y el análisis intentados, vale la pena hilvanar algunas reflexiones pensando en el futuro.

La primera es que, a pesar de no estar acabadamente enraizadas en la sociedad y de adolecer de una fragmentación todavía excesiva, las aún hoy -y quizá por algún tiempo más- débiles asociaciones de consumidores y usuarios están llamadas -o deberían estarlo- a ser un actor con promisorias posibilidades en lo que respecta al control, la elevación de la calidad y la búsqueda de soluciones ingeniosas a conflictos individuales y colectivos en la medicina y la Sanidad en España. En una suerte de dialéctica entre el movimiento asociativo y los usuarios y consumidores de a pie - en la que el protagonismo y la relevancia de las entidades tiene que ser motor y efecto de la creciente conciencia social de derecho-, puede alumbrar una voz que, revestida de autonomía y légitimidad, represente los intereses de quienes constituyen la demanda sanitaria.

La segunda reflexión es que, inexorablemente, se debe it hacia una mayor especialización sectorial de parte de las entraades. 'Huèga exagetar lo vasta y multifacética que actualmente es la Sanidad y la abundancia de riesgos inherentes a las prestaciones médicas, riesgos que pueden acarrear serios daños y perjuicios a los pacientes. Abogar por la especialización significa, por un lado, que las entidades que trabajan sobre el conjunto de los rubros del consumo encaren programas de Sanidad y, por otro, que se estimule la creación, acompañada de su interrelación, de asociaciones de usuarios específicamente sanitarios. Un recurso estratégico en ese sentido son los asesores, consultores y/o peritos médicos, indispensables para encami- 
nar más eficazmente la acción de las organizaciones en esta dimensión, de modo de poder desechar - y explicar razonadamente el porqué al reclamante- las denuncias no viables, pero también para discernir y apuntalar aquellas en las que pueden inferirse reales irregularidades técnicas y asistenciales. Un escollo para contar con estos recursos humanos es el corporativismo y la solidaridad mal enfocada que asiduamente campea entre los profesionales médicos, lo cual hace que de momento no parezca que sean muchos los dispuestos a colaborar con los usuarios y sus entidades a la hora de clarificar episodios en los que están involucrados otros facultativos o instituciones sanitarias.

Una tercera reflexión es que habría que plantearse y ensayar la conformación de Juntas de Arbitraje en el sector sanitario, con el concurso de organizaciones de consumidores y usuarios, colegios, sindicatos o asociaciones médicas, cámaras de seguros y de sanatorios privados, Administración, etcétera, para oir a denunciantes y denunciados. En muchos casos $-\mathrm{y}$, sobre todo, en los menos graves en las que serían particularmente pertinentes-, las Juntas podrían mediar y conciliar, hasta alcanzarse, si es que caben, reparaciones y compensaciones por carriles pecuniaria y moralmente menos costosos para galenos y pacientes que los judiciales.

Por último, para que los buenos propósitos no queden reducidos a papel mojado, debe dinamizarse el funcionamiento de los órganos colegiados de participación y asesoramiento al interior de los dispositivos sanitarios, órganos en los que las entidades de consumidores y usuarios pueden ser de máxima utilidad para el mejoramiento de la atención. Por ende, hay que vencer las inercias institucionales y las resistencias al cambio, y compartir y consensuar con estas entidades y otros estamentos las decisiones de planificación, vigilancia y evaluación de la asistencia. Si de verdad no se cree que los pacientes son meros recipiendarios pasivos de servicios cuyo. único destino es pasar fugazmente por los centros, y si se piensa que las asociaciones de consumidores y usuarios pueden representar sus puntos de vista y expectativas, entonces es impostergable acelerar y rutinizar el desarrollo de tales órganos colegiados. 


\section{BIBLIOGRAFIA}

Cri\%. CiNtero. Pepa (1988): Actitudes y comportamientos de los españoles ante el consumo. Madrid. Centro de Investigaciones Sociológicas (Estudios y Encuestas núm. 14).

DefeNSOR DEl PLeBlo (1988): "Informe sobre sistema sanitario público", Madrid, mimeo. Hamilton. Patricia (1982): Healtb care consumerism. St. Louis, The C. V. Mosby Company. INSALUD (1990): Indicadores de actividad bospitalaria. Año 1989. Madrid. Servicio de Información y Documentación.

Instituto NaCional de Estadística y Ministerio de Sanidad y Consumo (1990): Estadistica de establecimientos sanitarios con régimen de internado. Año 1987. Madrid, INE y MSC. Ministerio de SANidad y Consumo (1989): Memoria estadistica del Ministerio de Sanidad y Consumo 1986. Madrid, Centro de Publicaciones, Documentación y Biblioteca.

Pérez Oliva, Mercedes (1989): "Conciencia de consumidor", Temas de Nuestra Epoca (El Pais). año III, núm. 85, 29 de junio.

SERVicio de ORganizaciones DE CONSUmidores (1984): "Datos básicos sobre las organizaciones de consumidores españoles», Estudios sobre Consumo. núm. 1, abril. 
NOTAS DE INVESTIGACION 